\title{
Arbor
}

\section{Las relaciones de género: Imágenes y realidad social}

\section{Gloria Nielfa Cristóbal}

Arbor CLXIX, 666 (Junio 2001), 431-460 pp.

El objetivo propuesto es el análisis de las relaciones de género en Madrid en torno a 1900, a través del examen de algunos aspectos, como la educación, el trabajo, la forma en que se combinan género y clase en la vida social, el debate ideológico, y todo ello atendiendo tanto a los modelos que se difunden como al funcionamiento de la realidad social. Se ha tratado de captar los rasgos que definen un momento determinado, el del cambio de siglo, si bien sólo adquieren todo su sentido considerados dentro de la evolución de un proceso histórico.

Analizar las relaciones de género que se desarrollan en una sociedad es penetrar en uno de los aspectos esenciales de la civilización en esa etapa histórica, en este caso la transición intersecular, tal como ha sido definida por Jover ${ }^{1}$. Encontraremos así elementos que permitirán medir el grado de modernización de la sociedad madrileña en ese período.

\section{Algunas notas de demografía}

Madrid, ciudad de inmigración, presenta un mayor desequilibrio entre las cifras de su población femenina y masculina que el conjunto español, y que otras capitales de provincia. Así, si en la España de 1900 hay 95,3 varones por cada 100 mujeres, en el caso madrileño la cifra es de 85,5 (291.925 mujeres y 249.628 varones, según el censo de 1900), lo que se explica por las mayores expectativas de empleo que la capital ofrecía a las mujeres, en relación con otras zonas de 
España. No ocurre así en la edad infantil, pues vemos que las cifras de «niños sin profesión por razón de su edad» son casi iguales para niños y niñas, con ligero predominio de los primeros: 40.054 y 39.876, respectivamente. Ese desequilibrio también varía mucho de unos distritos a otros: Buenavista, Centro y Congreso serían los distritos más feminizados, con menos de 80 hombres por cada 100 mujeres, hecho que, junto a otros factores, seguramente hay que poner en relación con la abundancia en ellos de servicio doméstico, mayoritariamente femenino ${ }^{2}$.

Una pauta típicamente urbana, como es el retraso en la edad de matrimonio, es claramente apreciable en el caso madrileño (en 1900 sólo están casadas un $24 \%$ de las mujeres comprendidas entre los 16 y los 30 años, frente a un 34,5\% en Barcelona y un 40,1\% en España). Muchas mujeres que trabajan fuera del hogar posponen el matrimonio, ya que éste significará en muchos casos, dados los modelos de género vigentes, el abandono del empleo. Claro que las necesidades económicas obligarán a muchas de esas mujeres, una vez casadas, a contribuir con el producto de su trabajo al sostenimiento de la economía familiar, además de ocuparse del trabajo doméstico y del cuidado de los hijos, aspecto sobre el que se volverá más adelante. Retenemos, pues, por el momento, el mayor número de mujeres, y la elevada presencia de solteras ${ }^{3}$.

\section{Roles de género y su transmisión por la educación}

La sociedad liberal ha puesto especial énfasis en la construcción diferenciada de lo masculino y lo femenino. La teoría de las dos esferas, al establecer una rígida separación entre lo público, considerado como ámbito masculino, y lo privado, que atribuye a las mujeres, trata de naturalizar una determinada división de funciones, de espacios de actuación, y también de valores. Se exaltan la maternidad y la domesticidad como únicos polos de la vida de las mujeres, que aparecen siempre definidas a través de sus relaciones con los varones. La familia, considerada célula de la sociedad, es una unidad regida por la autoridad del marido y padre. Estamos ante un discurso sancionado por las leyes, como podemos observar a través del Código Civil de 1889, del Código Penal de 1870 o del Código de Comercio de 1885. De este modo, algunos de los cambios más importantes del siglo XIX, la ciudadanía y la extensión de la educación, al aparecer impregnados de esas pautas 
Las relaciones de género: Imágenes y realidad social

de género, han agrandado la distancia social entre varones y mujeres, respecto a épocas anteriores ${ }^{4}$.

Los valores de género se trasmiten a través de la educación. Considera Emilia Pardo Bazán en 1892 que en España son mayores las diferencias que las semejanzas entre la educación de hombres y mujeres, a pesar de las afinidades de métodos y programas de enseñanza, por «el sentido diametralmente opuesto de los principios en que ambas educaciones se fundan»: la masculina, en el postulado optimista, o de fe en la perfectibilidad de la naturaleza humana; la femenina, en el pesimista, según el cual existe una contradicción entre la ley moral y la ley intelectual, cediendo en daño y perjuicio de la moral cuanto redunde en beneficio de la intelectual. Así, «la intensidad de la educación, que constituye para el varón honra y gloria, para la hembra es deshonor y casi monstruosidad». Pero observa asimismo en la sociedad civilizada una tendencia a invertir esos dos datos: que se camina a reducir las diferencias y aumentar las relaciones. Veamos en qué punto de esa evolución se encuentra el caso madrileño ${ }^{5}$.

En el Madrid de 1900, saben leer y escribir el $76 \%$ de los varones y el 59\% de las mujeres; si nos ceñimos a los mayores de 10 años, los porcentajes son del 88 y del $66,7 \%$, respectivamente, según los datos de A. Tiana. Se trata de niveles muy superiores a los del promedio español, dadas las mayores oportunidades educativas que la capital ofrece, si bien alejados de los que se registran en países de Europa occidental y nórdica. Todavía una encuesta publicada en 1900 mostraba la existencia de la idea de que aprender a leer y escribir abría las puertas de la seducción y de que las mujeres no necesitaban educación para servir a Dios y cumplir con su obligación doméstica ${ }^{6}$.

Con datos de 1895, Hauser puso de manifiesto la mayor presencia de niños que de niñas en el conjunto de las escuelas públicas madrileñas, frecuentadas sobre todo por hijos de las clases populares, en las que las madres retenían a las niñas a su lado para contar con su ayuda en la casa, mientras que en las escuelas privadas era más elevado el número de niñas, al enviar las familias acomodadas a la escuela a todos sus hijos, niños y niñas. Las cifras de alumnos de primera enseñanza que figuran en el Censo de 1900 (entiendo que referidas a la enseñanza pública) están bastante igualadas entre niños y niñas, con un ligero predominio de los primeros. Manteniéndose la separación de sexos, ya que los sectores conservadores consideraban la coeducación como fuente de promiscuidad y como un atentado al pudor de las niñas, la medida de aproximación entre la enseñanza masculina y femenina fue el Real Decreto de 26 de Octubre de 1901, que fijó las 


\section{Gloria Nielfa Cristóbal}

materias de estudio en la Enseñanza Primaria Pública, con carácter común, excepción hecha de las labores en el caso de las niñas ${ }^{7}$.

$\mathrm{Al}$ ascender a otros niveles del sistema educativo es cuando el desequilibrio en función del género se hace más patente. El apartado del Censo que engloba a «estudiantes de segunda enseñanza, Facultad y carreras especiales», arroja, para la capital, una cifra de 10.824 varones y 1.125 mujeres. Resulta difícil desagregar dichas cifras, pero está claro que, a diferencia de lo que sucedía con los varones, la presencia de mujeres en Bachillerato y en Facultades universitarias era meramente testimonial, por las razones que más adelante se expondrán. En cambio, los estudios de Magisterio habían venido siendo, a lo largo de las cuatro décadas anteriores, los de más alto nivel intelectual abiertos a las mujeres en España, al prepararlas para ejercer la enseñanza primaria de las niñas, tarea acorde con las funciones sociales que se les asignaban. A ello se añade, en nuestro caso, la importancia de la Escuela Normal Central de Maestras, centro donde se formaba el profesorado de las otras Escuelas Normales, si bien desde la reforma de 1889 bastaba con estudiar en ella el último curso para obtener el título de maestra Normal. En cuanto a la equiparación de los planes de estudios de maestros y maestras, excepto en lo que se refiere al mantenimiento de una asignatura de Fisiología, higiene y gimnasia para ellos, y otra de Labores y Corte para ellas, procede de las reformas de 1898 y $1900^{8}$.

Junto a la enseñanza oficial, es necesario mencionar la existencia de la Asociación para la Enseñanza de la Mujer, presidida a la altura de 1900 por Gumersindo de Azcárate, tras la muerte en 1898 de Manuel Ruiz de Quevedo, continuador en su día de la obra de Fernando de Castro. Desde 1893 se hallaba instalada en un edificio financiado por suscripción pública en la calle de San Mateo. Cuando empieza el siglo, y a pesar de las dificultades económicas que la Asociación había venido atravesando en los últimos años, seguía sosteniendo una serie de Escuelas pioneras en un terreno tan abandonado como el de la preparación profesional de las mujeres. Se trataba de la Escuela de Institutrices, que sirvió de modelo e impulso para la transformación de la propia Escuela Normal Central de Maestras, y que entró en declive a partir de 1900; de la Escuela de Comercio, que hasta 1897 había contado con el apoyo económico del Círculo de la Unión Mercantil, apoyo que se interrumpió cuando el Círculo decidió crear sus propias enseñanzas; y, desde el curso 1895-1896, de la Escuela de Bibliotecarias y Archiveras. A ellas se unían desde los años 80 una Escuela Primaria Elemental, a la que asistían niñas y niños, y otra Preparatoria; una Escuela de 
Las relaciones de género: Imágenes y realidad social

Segunda Enseñanza creada en 1894, y las llamadas clases especiales: Idiomas, Dibujo, Música, Corte y Confección. Conviene recordar que desde los años 80, la Asociación colaboraba con el municipio, admitiendo en sus Escuelas con matrícula gratuita a cincuenta alumnas procedentes de las escuelas públicas municipales, convirtiéndose así en delegada del Ayuntamiento hasta que éste pudiera llevar a cabo su aspiración de crear un Centro Superior Femenino. También recibía el apoyo de instituciones públicas y privadas de la vida madrileña, si bien con interrupciones, que obligaban a ciertos reajustes. En total, a principios de siglo, son unas 7.000 las alumnas que han pasado por sus aulas, y la iniciativa se ha extendido a diferentes ciudades españolas. Pocos años después, en 1906, establecerá un convenio con la Unión Iberoamericana para la creación del Centro Iberoamericano de Cultura Popular Femenina ${ }^{9}$.

Dentro de lo que se pueden llamar enseñanzas profesionales, es especialmente numerosa la presencia de mujeres en el Conservatorio de Música y Declamación, si bien para muchas no tiene precisamente ese carácter profesional, sino el de cultura de adorno, tan querido para sus hijas por las clases medias y acomodadas:

«Siendo el matrimonio y el provecho que reporta la única aspiración de la burguesa, sus padres tratan de educarla con arreglo a las ideas o preocupaciones del sexo masculino...transigen y hasta gustan de los idiomas, la geografía, la música y el dibujo, siempre que no rebasen del límite de aficiones y no se conviertan en vocación seria y real» ${ }^{10}$.

En cambio, las mujeres que acuden a las Escuelas de Artes e Industrias sí lo hacen guiadas por una finalidad práctica, teniendo en cuenta la necesidad que se deja sentir en sectores de la clase media de preparar a sus hijas para una futura integración en el mercado laboral. Además, haber obtenido premio en Dibujo en la Escuela de Artes y Oficios era un requisito para las alumnas que querían acceder al examen de ingreso en la Escuela Especial de Pintura, Escultura y Grabado, algo que no se exigía a los alumnos.

Dentro de la educación artística es interesante considerar el caso de esta Escuela Especial de Escultura, Pintura y Grabado, que en el curso 1902-1903 cuenta con 150 alumnos y 17 alumnas. Ya se ha aludido al papel de la pintura y el dibujo como parte de la educación de adorno que se consideraba apropiada para una señorita. Al mismo tiempo, las mujeres habían venido estando excluidas de la clase de dibujo del natural, considerada básica en la formación de los grandes artistas, al entender como indecorosa para ellas la copia de desnudos. 
«Pintar platos, decorar tacitas, emborronar "un efecto de luna", bueno; frecuentar los museos, estudiar la naturaleza, copiar del modelo vivo, malo malo» ${ }^{11}$.

No cabía así la dedicación a la pintura de historia; se imponía la de flores, paisajes y animales. La asignatura de Anatomía Pictórica no admitió a mujeres hasta el último lustro del siglo XIX, y la primera alumna que obtuvo un diploma en ella, Adela Ginés, en 1894, lo hizo examinándose por libre, cuando ya era una pintora conocida y profesora de la Asociación para la Enseñanza de la Mujer ${ }^{12}$.

Otros estudios, cuya finalidad es el ejercicio de una profesión socialmente aceptada para las mujeres, son los de Matrona, si bien presentan el inconveniente de que se requiere la mayoría de edad para comenzarlos, dejando así un intervalo demasiado largo desde el final de la enseñanza primaria. Por otra parte, en el seno del Instituto Rubio del Hospital de la Princesa se creó en 1895 la Escuela de Enfermeras de Santa Isabel de Hungría, con alumnas externas e internas. Una institución modelo para Tolosa Latour, y que ha sido considerada como iniciadora de la moderna enfermería en España, si bien sus pautas arrancaban de una concepción del sacrificio como un rasgo esencialmente femenino ${ }^{13}$.

En cuanto al Bachillerato, el nivel que en el caso de los varones agrupa a la mayoría de los estudiantes de enseñanza media, cuenta solamente con ocho alumnas en la provincia de Madrid en 1900. Se trata de unos estudios considerados como antesala de la Universidad o medio de preparación para empleos cualificados, y que deben realizarse en los institutos públicos, de carácter mixto, ya que los centros privados todavía no los ofrecen a las estudiantes. Se puede recordar el testimonio que aporta E. Pardo Bazán en el Congreso Pedagógico de 1892, tratando de vencer las resistencias a la coeducación en la sociedad de la época, y que al mismo tiempo deja constancia del peso que en ella tenían:

«Mi hija mayor cursa el bachillerato en el Instituto del Cardenal Cisneros y sólo gratitud debe a los dignos profesores que la han rodeado de la mayor consideración y protección, y a los alumnos que jamás la han molestado ni con la más leve inconveniencia» ${ }^{14}$.

Por lo que se refiere a la Universidad, se puede afirmar que hasta 1910 sus puertas estarán solamente entreabiertas para las mujeres. En efecto, no será hasta ese año cuando se suprima el requisito que obligaba a las estudiantes que deseaban realizar matrícula oficial a 
Las relaciones de género: Imágenes y realidad social

solicitar un permiso individualizado, tras lo cual se pedían informes a los profesores sobre si se consideraban capaces de mantener el orden en las aulas, a pesar de la presencia femenina, informes que en todos los casos fueron afirmativos. Sabemos de alumnas que asistían acompañadas por sus padres o hermanos, o que se sentaban en clase junto al profesor. Esta era la situación en el curso 1900-1901, en el que tres mujeres estudiaban carreras en la Universidad Central: dos en Filosofía y Letras, y una en Farmacia. Hasta entonces, en dicha Universidad, cinco mujeres habían conseguido la Licenciatura en Filosofía y Letras (dos de ellas, examinándose por libre, tras haberse preparado en el Instituto Internacional de San Sebastián, dirigido por Alice Gordon Gulick, y que en 1903 se instalaría en Madrid), y dos en Farmacia, de las que también una procedía del Instituto Internacional. El Instituto, antiguo Colegio Norte Americano, tuvo su origen en la labor de educación femenina impulsada por una misionera protestante, la señora Gulick, que trató de implantar en España el modelo educativo de los colleges femeninos norteamericanos. Por otra parte, a la altura de 1900 eran cinco las mujeres que habían obtenido el Doctorado: tres en Medicina y dos en Filosofia y Letras. En cuanto a las Escuelas de Ingenieros, todavía eran un ámbito exclusivamente masculino ${ }^{15}$.

Hemos podido seguir hasta aquí la forma en que el prejuicio hacia la enseñanza conjunta, en unas mismas aulas, de hombres y mujeres, empujó a éstas en distintos niveles de estudios hacia la enseñanza libre, con las consiguientes desventajas económicas y de preparación:

«La que suscribe desea matricularse con carácter oficial...pues su condición de hija de viuda no la consiente hacer los grandes gastos que supone la enseñanza privada, cuando con tanta economía puede seguir los cursos oficiales y participar al mismo tiempo de las ventajas que reportan al alumno las explicaciones orales y el material científico de los centros sostenidos por el Estado» ${ }^{16}$.

Todo ello en una sociedad, en que, como decía Concepción Arenal, las personas honestas de ambos sexos se encontraban en los teatros, en los templos y en las corridas de toros. El hecho ha llevado a R. $\mathrm{M}^{\mathrm{a}}$ Capel a preguntarse si lo que realmente se temía, más que la convivencia en un mismo espacio, era la demostración de que las capacidades podían ser equiparables:

«En última instancia, no se temen tanto los "males" del mutuo contacto físico como el reconocimiento de la igualdad en sus capacidades intelectuales, aptitudes y fines que llevaba implícita la educación conjunta» ${ }^{17}$. 


\section{Trabajo y familia ¿incompatibilidad o interdependencia?}

Conocer las actividades productivas en que hombres y mujeres se ocupaban por entonces en Madrid requiere algunas consideraciones previas. En primer lugar, la necesidad de tener en cuenta tanto las que se realizan en el ámbito del mercado como otras, relacionadas con la reproducción biológica y social. Los cambios introducidos por la industrialización habían afectado a la organización de la producción $\mathrm{y}$ al sistema de reproducción $\mathrm{y}$, por tanto, al modelo social de género, dejando también su huella en las clasificaciones ocupacionales. Así, una primera aproximación a la distribución por actividades de la población es la que nos ofrecen los Censos, si bien presenta importantes limitaciones. Junto a problemas generales de clasificación, hay que señalar la invisibilidad de muchas actividades económicas realizadas por mujeres, y la forma en que el avance del discurso de la domesticidad lleva a la ocultación de una parte importante del trabajo femenino ${ }^{18}$.

En el Censo de 1900, a diferencia de los anteriores, y de acuerdo con los criterios adoptados por el Instituto Nacional de Estadística, hay un apartado para "Miembros de la familia, dedicados a trabajos domésticos", pero en los resúmenes provinciales y de capitales se engloba con el de "individuos sin profesión y de profesión desconocida», dando así, como ha señalado P. Pérez-Fuentes, un sentido de improductividad al trabajo realizado por las mujeres en los hogares y que en realidad abarcaba facetas relacionadas con la subsistencia de la familia - trabajo doméstico-, con la reproducción —cuidado de los hijos- y con el mercado -el llamado trabajo a domicilio-. Es en ese epígrafe donde aparecen registradas la mayoría de las mujeres en Madrid: 180.416, junto a 38.229 varones. Figuran en él más de 83.000 casadas y de 29.000 viudas, que podemos considerar amas de casa, aparte de que también lo sean las que realizan otra actividad fuera del hogar. El trabajo de estas amas de casa proporcionaba un conjunto de bienes y servicios, que se acentúa cuando escasean los recursos con que adquirir esos bienes en el mercado, es decir, en la clase trabajadora, y en épocas de crisis. Además, conviene recordar la existencia en Madrid, a la altura de 1900, de barrios en los que todavía no se han producido algunos de los avances en higiene urbana y equipamiento que han eliminado algunas de las tareas más penosas que se realizaban en los hogares en épocas anteriores; vemos así, en la zona sur de los distritos de Hospital, Inclusa y Latina, casas que carecen de agua y hay que ir a buscarla a la fuente; barrios como los de La Prosperidad y La Guindalera que carecen de alcantarillado, y donde la inexistencia 
de retretes obliga a verter aguas sucias y materias fecales fuera de casa, según el testimonio de Hauser. Por otra parte, si recordamos que la tasa media de natalidad en Madrid está en un 30 por mil en 1905, y la persistencia de una importante mortalidad infantil (con grandes diferencias por distritos y barrios en ambos factores) vemos cómo embarazos, partos, lactancia y cuidado de los hijos ocupan un tiempo importante en la vida de muchas mujeres. Más llamativa resulta la presencia de casi 68.000 solteras en ese apartado. En el caso de Barcelona, con un contingente de población prácticamente igual al de Madrid, son mucho más reducidas las cifras de solteras y viudas en este epígrafe, 51.000 y 19.000 , respectivamente, y también la de casadas, 78.000, es inferior a la madrileña; una natalidad más baja y una diferente estructura productiva deben ser tenidas en cuenta a la hora de valorar el hecho ${ }^{19}$.

La asimetría por razón de género es también la nota dominante en el renglón del Censo que sitúa a quienes se definen por la posesión de propiedad territorial y urbana. Si bien en los resúmenes de capitales aparece este concepto englobado con agricultura, cría de animales, pesca y caza, lo que le da un carácter confuso, cabe pensar que el mayor peso numérico corresponda a las cifras de propietarios de suelo. El predominio de los varones es abrumador: 34.723 , frente a 2.679 mujeres, más del $40 \%$ de ellas, viudas. La comparación con el caso barcelonés, que registra cifras más altas en ambos casos, muestra sobre todo una gran diferencia en el caso de las mujeres, con predominio de casadas y solteras, lo que sin duda debe relacionarse con el sistema legal del matrimonio y de la herencia en el caso catalán.

Un apartado, minoritario en la época por razones demográficas y de ausencia de política social, y cuya distribución entre hombres y mujeres hay que entender en relación con los modelos de género vigentes respecto a la actividad profesional, es el de «Retirados y pensionistas»: 2.215 varones y 4.399 mujeres. Mientras que casi el $67 \%$ de los varones son mayores de 60 años, y más de la mitad casados, las mujeres que lo integran se reparten entre solteras y viudas, con predominio de estas últimas, y menos del $22 \%$ alcanzan la citada edad de los 60 años. Se trata, por tanto, de retirados en el primer caso, y en el de las mujeres, de pensionistas por razón de orfandad y viudedad.

Como antes señalaba, los censos no dan cuenta de toda la actividad femenina, ni siquiera de toda la actividad femenina dirigida al mercado que se realiza en la capital. La existencia de mercados sumergidos de bienes y servicios a cargo de las mujeres en las ciudades es un hecho conocido: lavanderas, planchadoras, costureras, vendedoras ca- 


\section{Gloria Nielfa Cristóbal}

llejeras, patronas de huéspedes, etc., que conocemos a través de otras fuentes: literarias, de prensa, gráficas. En esas actividades se ocupaban, sin duda, muchas mujeres que el Censo cataloga como dedicadas a trabajos domésticos, o como pensionistas, dada la escasa cuantía de las pensiones. Veamos algunos ejemplos.

La documentación municipal informa de la existencia de 77 lavaderos en la capital en 1903, situados en su mayoría a lo largo del Manzanares, principalmente en el distrito de Palacio, y en menor medida, en el de Latina, siendo numerosos los testimonios gráficos que han mostrado la extensión que llegaron a ocupar en la zona cercana al río; otras veces, se trata de edificios con pilas de cemento situados en la zona de las Rondas. En la mayor parte de los casos figura un varón al frente del lavadero, si bien es un oficio desempeñado por mujeres. La autobiografía de Arturo Barea nos permite, a través de la figura de su madre, acercarnos a la vida de una de esas lavanderas, cuya actividad, básica para su sustento y el de sus hijos, escaparía muchas veces a la estadística.

«Cuando murió mi padre, éramos cuatro hermanos y yo tenía dos meses. Le aconsejaban a mi madre - según me ha contado- que nos echara a la Inclusa, porque con los cuatro no iba a poder vivir. Mi madre se marchó al río a lavar ropa. Los tíos nos recogieron a mí y a ella; los días que no lava en el río hace de criada en casa de los tíos y guisa, friega y lava para ellos; por la noche se va a la buhardilla donde vivo con mi hermana Concha» ${ }^{20}$.

Asimismo encontramos información en la prensa, a menudo en artículos de tono costumbrista, que muestran una importante realidad laboral, que contradice ciertos patrones muchas veces repetidos:

«Parece increíble que esas mujeres puedan soportar un trabajo tan rudo y persistente. Cierto es que las enfermedades harán muchas bajas en ellas. Pero iqué diablo! más bajas hace el hambre, podríamos decir parodiando la frase del infortunado matador de toros Espartero.

Por el género de vida a que las sujeta su profesión, las lavanderas -y hablo en tesis general- viven fuera de su casa. El lavadero es su taller y su morada. Allí comen, interrumpiéndose a veces porque sopla viento fuerte y ha hecho que se enganche alguna prenda ó que vuele (...) Allí, en el lavadero, se puede aprovisionar de todo. La fiadora que va todos los días o todas las semanas á cobrar el perro chico ó el real del pañuelo, de la toquilla, de la falda o del mantón dado a rédito hace propaganda entre las que todavía no ha logrado ver entre 
sus garras (...) Lavada ya la ropa y tendida, el sol y el aire se encargarán de secarla. Si el sol falta, la ropa entrará mojada en los sacos, y las lavanderas tendrán que tenderla en su casa (...) ${ }^{21}$.

Entre las actividades remuneradas que figuran en el Censo, el servicio doméstico es una de las más numerosas en Madrid y la que ocupa a más mujeres: 32.100, frente a 7.200 varones. (En Barcelona, con porcentajes más altos de población dedicada a la industria y al comercio, las cifras son 17.011 y 2.161 respectivamente). El bloque mayoritario lo forman las solteras (más de un $80 \%$ de las sirvientas), procedentes en muchos casos de la inmigración rural y en otros de los barrios populares de la ciudad. El análisis del servicio doméstico a través de fuentes cualitativas, en este caso unas memorias, ha permitido observar la diferenciación de tareas y de salarios que se establece entre criados y criadas, el mayor prestigio social que supone para los amos el contar con personal masculino, y la doble moral mantenida en las familias burguesas en relación con las sirvientas, que presenta especiales características en el caso de las nodrizas. La seducción de la criada por parte del «señorito» y su indefensión legal es algo a lo que se alude en los chistes de la prensa ${ }^{22}$.

En las diferentes industrias, el citado Censo registra un total de 35.337 varones, muy numerosos en edificación, artes gráficas, etc., y 10.084 mujeres, si bien la Memoria del Ministerio de Fomento de 1905 eleva al 30\% la proporción que representan las mujeres en profesiones industriales y en artes y oficios en la ciudad de Madrid, citando las siguientes profesiones: bordadoras, bruñidoras, camiseras, cigarreras, lavanderas, sastras, corbateras, corseteras, modistas, guarnecedoras de sombreros, guarnecedoras de calzado, floristas, costureras, gorreras, guanteras, tapiceras, fabricación de sobres y de cajas de cartón, encuadernadoras, sombrereras, etc. ${ }^{23}$

Una buena parte de las actividades que se acaban de citar se engloban dentro de la industria del vestido y tocado, la confección, realizada en talleres y a domicilio, muchas veces por encargo de las camiserías y tiendas de ropa blanca. El trabajo a domicilio, defendido como beneficioso para la familia obrera por la presencia de la madre en el hogar, ofrecía notables ventajas para los empresarios, por el ahorro de instalaciones, de amortización de capital fijo, de funciones de organización y vigilancia del personal, así como por quedar a salvo de reivindicaciones obreras, a pesar del pago de jornales ínfimos. Para las obreras, dichas condiciones se traducían en la necesidad de realizar jornadas agotadoras, aun para conseguir salarios de hambre, eliminando así la teórica posibilidad de compaginar el trabajo con el cuidado de la familia. Un ejemplo de ese 
trabajo a domicilio es el que presenta Blasco Ibáñez, en La horda, publicada en 1905, a través de la figura de Feli, la muchacha que tras haberse ido a vivir con su novio, y encontrándose embarazada, no se atreve a volver a la fábrica de gorras donde trabajaba antes. Acuciada por la necesidad económica, toma la decisión de trabajar para un taller, haciendo flores para corsés y emballenándolos.

«Maltrana, al despertar, veía a Feli ante un montón de corsés, cosiendo animosamente (...) Isidro, al volver a su casa a altas horas de la noche, tenía que hacer grandes esfuerzos para que se acostase.

-Déjame acabar esta docena- decía sin levantar la cabeza, tenaz en el trabajo, deseosa de no perder un segundo (...)

Feli percibía cincuenta céntimos por cada docena de corsés. Apenas si trabajando día y noche podía juntar un par de pesetas» ${ }^{24}$.

Un modelo distinto es el que representan las 3.700 trabajadoras de la Fábrica de Tabacos. Un 70\% de las empadronadas en 1900 había nacido en Madrid y la mayoría residían cerca de la fábrica, con especial concentración en los barrios de Huerta del Bayo, Cabestreros, Peñuelas y Miguel Servet, en el distrito de Inclusa, lo que se explica por la tradición artesanal del oficio. Predominan en ese momento entre las cigarreras las mujeres maduras, la mayoría viudas, muchas casadas; un $37 \%$ se declaran «jefas de familia». Su salario es central en el presupuesto de sus familias, y sus responsabilidades domésticas representarán un factor clave en su permanencia en la fábrica. Por ello, en sus luchas obreras veremos al mismo tiempo la importancia de las reivindicaciones salariales, y las de aquellas que podemos considerar familiares, como las de exigir espacios y tiempo para atender a sus hijos en el horario de trabajo. Es conocida la existencia de la Escuela-asilo para hijos de cigarreras, en la calle de Embajadores, y del Colegio de San Alfonso, contiguo a la fábrica.

«Así, en su comportamiento y compromiso colectivo ...se mezclan asuntos públicos y privados, rasgos preindustriales y modernos, reivindicaciones laborales y domésticas, es decir, el taller y la casa como dos caras del mismo universo» ${ }^{25}$.

¿Cuáles eran las posibilidades, para el resto de las obreras, de dejar atendidos a sus hijos pequeños durante su jornada de trabajo, aparte de las redes de solidaridad establecidas por las propias mujeres, 
en la familia o en la vecindad? Debemos a Hauser la información sobre el tema. Aludiendo a lo que en Francia se denominaba crèche, institución destinada al cuidado de los lactantes mientras sus madres trabajan, menciona la existencia del Asilo para hijos de lavanderas, sostenido por Patrimonio Real, cerca de la estación del Norte, destinado a niños destetados, a partir de cinco meses; y como verdadera crèche, el establecimiento fundado por los marqueses de Aledo en 1893, cerca de la plaza de la Cebada y que dio origen a una sociedad que a la altura de 1900 sostiene cuatro asilos gratuitos (a diferencia del modelo francés, donde las obreras pagan una pequeña cantidad), con un total de 200 plazas, situados respectivamente en la plaza de la Cebada y en las calles de los Artistas, de Zurita y de Santa Feliciana. Eso parece ser todo. Para que se multiplique el número de establecimientos de este tipo, Hauser señala como factores necesarios la iniciativa particular, el apoyo del Estado (por medio de subvenciones y de leyes que deban cumplir los Ayuntamientos), y la propaganda por parte de las sociedades protectoras de la primera infancia ${ }^{26}$.

En el comercio, el modelo predominante es el de la pequeña tienda de carácter familiar, con raíces en el mundo artesanal, donde en muchos casos se hace invisible, a efectos estadísticos, el trabajo desarrollado por la esposa y por los hijos e hijas. Se trata de una actividad que se desenvuelve bajo la jerarquía familiar y aún no se ha producido un aumento importante en el número de dependientes. En esas condiciones, la distribución por estado civil de la población registrada como dedicada al comercio es claramente asimétrica en lo que se refiere a las mujeres y a los varones. Entre las primeras es notorio el predominio de las viudas; en 1900 el porcentaje que representan supera no sólo al de las casadas, sino incluso al de las solteras, lo que se debe al elevado número de mujeres que continúan al frente del negocio familiar tras la muerte de sus maridos. Una actividad, la comercial, que las mujeres casadas sólo podían ejercer con autorización marital, según el Código de Comercio de 1885. En esa época el número de mujeres que figuran como dedicadas al comercio en Madrid representa menos de un tercio de las que lo hacen en Barcelona, lo que nos habla de la forma en que se combinan factores legales con otros de tipo socioeconómico y relativos a los valores asumidos por las distintas capas sociales. Según datos de 1903, las mujeres aparecen al frente de pequeños establecimientos de los sectores de alimentación, bebidas y combustible: fruterías, lecherías, cacharrerías, tabernas, carbonerías, así como mercerías, lencerías, tiendas de novedades ${ }^{27}$. 
Como es sabido, la Ley de 13 de marzo de 1900, sobre trabajo de las mujeres y de los niños, marca el inicio de la legislación laboral en España, estableciendo un descanso obligatorio, no pagado, de tres semanas tras el parto, con reserva del puesto de trabajo; también permite a las madres trabajadoras la interrupción de su actividad durante una hora diaria para la lactancia, sin descuento de jornal. Esta Ley estableció asimismo la creación de las Juntas Provinciales y Locales de Reformas Sociales, que tenían por objetivo la inspección y vigilancia del cumplimiento de la Ley. Tres años más tarde se celebró un mitin de obreras en los Jardines del Buen Retiro, presidido por una planchadora, Josefa Ramos, en el que se pidió el nombramiento de inspectores del trabajo, a propuesta de las asociaciones, y retribuidos por el Gobierno, así como que se organizaran las Juntas de Reformas Sociales mal constituidas. Para ese momento sabemos de la existencia en Madrid de cuatro Sociedades de obreras, dirigidas a la resistencia al capital, que agrupan a unas trescientas mujeres: son la de Lavanderas, Planchadoras y Similares, desde 1902; la de Sobreras, la de Escogedoras de trapos (muy numerosas en los almacenes del Rastro), y la de Sastras; todas ellas han realizado ya alguna huelga con éxito, según explica Morato; otras doscientas mujeres están agrupadas en sociedades de carácter mixto, tales como las de zapateros, encuadernadores, constructores de cajas de cartón y fabricantes de bujías ${ }^{28}$.

Dos semanas después de la celebración del mitin citado, el ministro de la Gobernación, Antonio García Alix, encargó la formación de esas Juntas. En el caso madrileño, la provincial no se había constituido, y la local solamente se había reunido cuatro o cinco veces ${ }^{29}$.

La escasez de trabajo, los bajos salarios femeninos, la falta de instrucción y los patrones de género vigentes daban como resultado la existencia de un número considerable de prostitutas, a pesar de que en el Censo la cifra de mujeres en el apartado «Mendigos, vagabundos y prostitutas» sea de 319. Vigente el Reglamento de 1877, en 1899 pasaban de 2.000 las mujeres matriculadas, estimándose en unas 15.000 las que ejercían clandestinamente la prostitución. Al igual que en la reglamentación de otros países europeos, antagonismos y prejuicios de clase y de género impregnaban todo lo relativo a la inspección sanitaria establecida. En autobiografías como la de Corpus Barga son numerosas las referencias, desde el punto de vista del cliente, a las casas de prostitución en el centro de Madrid a principios de siglo, situando las más caras en el barrio de Barquillo, como la de la Granadina, o las que se escondían en una casa elegante, bajo una placa de modista, y aludiendo a otras de condiciones míseras, por ejemplo, 
en Postigo de San Martín, pasando por las de Horno de la Mata o de la Corredera ${ }^{30}$.

Respecto al fenómeno del paro, podemos comprobar a través de diversas fuentes que su intensidad, tanto para los hombres como para las mujeres, era mucho mayor que la reflejada en el Censo, en el apartado de "Individuos momentáneamente sin ocupación»: 2.054 varones y 16 mujeres. Pero además, la exigüidad de la cifra en el caso de las mujeres, que no guarda proporción con su presencia en el mercado del trabajo, creo que merece algún comentario. Estamos observando la segmentación de ese mercado, y la presencia mayoritaria de las mujeres en el servicio doméstico, en el trabajo a domicilio, el recurso a la prostitución como fuente de ingresos. Cuando en 1899, el Ayuntamiento abre un Registro del Trabajo, del que me he ocupado en otro lugar, como medio de facilitar empleo a los parados, se apuntaron en él 631 personas, todos varones. Ninguna mujer de las que sin duda se encontraban en paro parece que se sintiera aludida en aquella convocatoria a los trabajadores para «facilitar las relaciones de aquéllos con los patronos, dar a conocer el número operarios disponibles...", del mismo modo que no habíamos encontrando mujeres que informaran ante la Comisión de Reformas Sociales, en los años 80, a pesar de que en el cuestionario se dedicaban unas cuantas preguntas al trabajo que aquéllas realizaban y a las condiciones en que lo hacían. Se diría que el concepto de parado se construía en masculino en el discurso, del mismo modo que estaba sucediendo con el concepto de trabajador, y el concepto de mujer trabajadora se concebía como problemático, y objeto de discusión para los varones. Aparte de las 6 solteras, 8 casadas y 2 viudas que figuran en las cifras censales, ¿cuántas de las 180.416 mujeres más arriba mencionadas como miembros de la familia estarían momentáneamente sin ocupación, es decir, en paro? ${ }^{31}$

Como pertenecientes a las órdenes religiosas, figuran 2.450 mujeres y 510 varones, aparte de los 840 integrantes del clero secular. Los establecimientos de la Beneficencia Pública en Madrid estaban a cargo de religiosas, principalmente de las Hijas de la Caridad de San Vicente de Paul. También, en el cambio de siglo, las Hijas de la Caridad de Santa Ana atendían el Hospital de San Juan de Dios, y la Congregación de las Siervas de María se dedicaba a la asistencia domiciliaria a los enfermos.

La Fuerza Pública (Ejército, Armada y Cuerpos de policía) supone un contingente masculino de casi 17.000 personas, número elevado que debe relacionarse con las funciones de Madrid como capital, puesto que en Barcelona la cifra es inferior a la mitad. 
La administración pública es un sector en el que aparecen censados 10.598 varones y 39 mujeres. Estas últimas son las pertenecientes a los servicios de Correos, Telégrafos y Teléfonos, únicos abiertos hasta el momento a la participación femenina. Si el ejemplo del empleo de mujeres en correos y telégrafos en otros países impulsó su puesta en práctica en España, su techo profesional quedó establecido en la categoría de «auxiliares temporeras» en 1884 (aspirantes terceras interinas desde 1896). La imposibilidad para las mujeres de alcanzar niveles más elevados llevó al cierre, en 1886, de la Escuela de Correos y Telégrafos que la Asociación para la Enseñanza de la Mujer había abierto en 1882. Las demás ramas de la Administración serán exclusivamente masculinas hasta el Estatuto de Funcionarios de 1918:

«Caso notable: las luchas por sostener el derecho de una mujer a regir el Estado, ensangrentaron a España durante medio siglo; en el momento presente, otra mujer ciñe la corona; la mujer, por consiguiente, puede en España, hacer y deshacer ministerios, declarar la guerra y sancionar la paz, pero no despachar un expediente en una oficina» ${ }^{32}$.

La enseñanza engloba 1.193 varones y 826 mujeres, con una desigual distribución entre los distintos niveles educativos. Las maestras representan el grupo profesional cualificado más importante dentro de la actividad femenina, colectivo que en 1883 consiguió la equiparación salarial con los maestros y que jugará un importante papel en la reivindicación de mejoras educativas para las mujeres. En la cúspide se encuentran las profesoras de Escuela Normal, de especial relevancia en el caso madrileño por la primacía de la Escuela Normal Central; se trata del grupo de mujeres con un mayor reconocimiento académico en la España del momento, si se tienen en cuenta las condiciones de excepcionalidad que todavía acompañan su acceso a la Universidad. Distinto significado tendrán las Escuelas Normales de Maestros, habida cuenta de la gama mucho más amplia de posibilidades culturales y profesionales abiertas a los varones. La discriminación salarial, en el caso de las Escuelas Normales, llegará hasta nuestro siglo, pese a las reclamaciones planteadas por las profesoras ${ }^{33}$.

Veremos a continuación la disparidad en las cifras censales de hombres y mujeres en otras profesiones que requieren un elevado nivel de instrucción. Lo que en el Censo se llama "profesiones médicas» es un colectivo de 2.265 varones y 35 mujeres. El contingente femenino está compuesto por matronas, alguna enfermera (los hospitales estaban atendidos por religiosas, como ya se ha señalado), y de forma excepcional, 
alguna médica. Es el caso de Concepción Aleixandre, ginecóloga que desde 1891 trabajaba en el Hospital de la Princesa, que al año siguiente consiguió romper la oposición a su ingreso en la Sociedad Ginecológica Española, y en 1902 fue nombrada Médica de Beneficencia Provincial en la Casa de Maternidad e Inclusa, manteniendo además una consulta privada. También ejercía la Medicina en el Madrid de 1905 (y quizá antes) Manuela Solís, otra ginecóloga, que había completado sus estudios en el Instituto Rubio del Hospital de la Princesa, y en París; trabajó en la Real Hermandad de la Esperanza (conocida como «del Pecado Mortal»), que asistía «sigilosamente a mujeres embarazadas de ilegítimo concepto», y en los Asilos la «Cuna de Jesús». Vemos aquí la forma en que se insertan profesionalmente en la sociedad española las ginecólogas, pues desde los mismos presupuestos que se esgrimían para impedirles el acceso a la Universidad y al ejercicio profesional, se estimaba muy recomendable que las mujeres fueran asistidas por otras mujeres. Por su parte, Trinidad Arroyo, la primera oftalmóloga española, desarrolló su actividad en el Consultorio de Niños de Pecho, en el Instituto Rubio y en el Asilo de Santa Lucía ${ }^{34}$.

Dos espacios cuya configuración es, y seguirá siendo durante décadas, exclusivamente masculina, son el de las profesiones judiciales, con una larga tradición, y el de Arquitectura e Ingeniería, de desarrollo reciente $y$ que ofrece por entonces en Madrid oportunidades de trabajo a los nuevos profesionales; en 1900 agrupan, según el Censo, a 2.600 y 495 personas, respectivamente:

«Madrid abre ahora un amplio mercado a nuevos profesionales como los ingenieros y arquitectos, que encuentran trabajo en la construcción de viviendas $y$ edificios oficiales» ${ }^{35}$.

El ámbito intelectual, literario y periodístico reviste en Madrid una particular importancia, como centro político del país y como sede editorial y de publicación de periódicos y revistas; además, es preciso mencionar la aparición de los «intelectuales» considerada como un hecho ligado precisamente a ese fin de siglo. En términos estadísticos, las cifras censales nos hablan de 371 varones y 8 mujeres dedicados a la literatura. Cabe pensar que muchas de las mujeres que escriben en ese momento en Madrid no aparecen registradas como tales. Una rúbrica mixta en su composición es la que agrupa a «copistas, estenógrafos y traductores», y que supone 655 varones y 10 mujeres ${ }^{36}$.

$\mathrm{El}$ examen de las relaciones de género que se desarrollan entre quienes escriben presenta un doble interés, ya que además de un sector 
de actividad, es un núcleo de elaboración de discurso. Es conocida la existencia de un gran número de escritoras durante el siglo XIX, ya que para ello no se requieren unos títulos o una contratación previa; si seguimos a Virginia Woolf, lo que una mujer necesita para poder escribir novelas es «tener dinero y una habitación propia», en un momento en que otras puertas profesionales se le cerraban. Si como señala P. Aubert, "para entender mejor el papel de los intelectuales, la significación y el alcance de su discurso y de su protagonismo en la vida pública, no puede separarse el análisis de las mentalidades del de sus lugares y sus medios de producción", parece oportuno considerar la influencia que el marco general de relaciones de género ejercía sobre la posición respectiva de escritoras y escritores dentro del mundo intelectual, lo que obliga a cuestionar las fronteras de lo público y lo privado ${ }^{37}$.

En el campo artístico se observan algunas transformaciones:

«El último tercio del siglo XIX ve surgir todo el sentido moderno del mundo del arte. La burguesía, como clase en ascenso, entra en el mercado artístico potenciando una serie de iniciativas privadas con una finalidad última: vender la obra» ${ }^{38}$.

En ese contexto, vemos cómo, a pesar de la vigencia de las ideas que conciben el genio como masculino y la repetición como femenina, un número creciente de mujeres trata de abrirse camino en el campo del arte, especialmente de la pintura, pasando del diletantismo a considerar su trabajo artístico como un modus vivendi. Así, se observa la presencia de obras pintadas por mujeres en las Exposiciones $\mathrm{Na}$ cionales de Bellas Artes y en otras de tipo privado, como las del Círculo de Bellas Artes, y los catálogos nos informan de los precios que ponían a sus obras. Respecto a la acogida por parte de la crítica, Estrella de Diego ha mostrado cómo en muchos casos se movía entre el paternalismo galante y el miedo a la competencia que las pintoras podían representar. Si en el Censo de 1900 figuraban 658 varones y 5 mujeres dedicados a Artes Plásticas, tenemos noticias de la celebración, en 1903, de una «Exposición de Pintura Feminista», en el Salón Amaré, que reunió a cuarenta expositoras, entre profesionales y aficionadas:

«En un país como el nuestro, lleno de preocupaciones y de prejuicios, donde pocas mujeres asisten a las clases y donde todavía se toman a broma los adelantos del feminismo, cuarenta mujeres que llevan sus trabajos a una exposición es un buen número» ${ }^{39}$. 
No sabemos a quién correspondió la iniciativa de la exposición, ya que, a diferencia de lo que sucedía en ese momento en distintos países europeos y americanos, no tenemos noticia de la existencia en España de asociaciones de mujeres $\operatorname{artistas}^{40}$.

El mundo del espectáculo ocupa, según el Censo que vengo citando, a 1.036 varones y 242 mujeres. El teatro es una profesión más aceptada que otras para las mujeres en la sociedad española del XIX, a pesar de las dificultades de conciliación con la vida del hogar. Así, en la prensa, son frecuentes las alusiones elogiosas a actrices como María Guerrero, María Tubáu, Rosario Pino, Carmen Cobeña, Loreto Prado, o a sopranos como Adelina Patti, María Barrientos.

«Todavía a principios de siglo, ser actriz es la profesión más brillante a que la mujer puede aspirar. Salir de la estrechez económica y del anonimato, afrontar la opinión pública, captar su atención y tal vez pasar a la posteridad no es una aventura trivial para nadie. Y la escena es desde una vocación a un escaparate» ${ }^{41}$.

\section{Relaciones de género y clases sociales}

La clase social y el género marcan el lugar ocupado por los individuos en la sociedad, lo que se traduce en diferentes espacios y pautas de sociabilidad.

M. Perrot ha señalado la calle, el mercado y el lavadero como los lugares clave de sociabilidad femenina urbana en las clases populares. Recordemos la existencia en el Madrid de principios de siglo de un gran número de puestos callejeros en los alrededores de los mercados, que prolongan la venta de los artículos alimenticios en un amplio espacio. La calle de la Corredera Alta, cercana al mercado de San Ildefonso, o la de la Ruda, próxima a la plaza de la Cebada, son ejemplos de ese ambiente donde se desarrollan lazos de unión entre las verduleras, y conflictos con los agentes de la autoridad, que a veces saltan a las páginas de la prensa ${ }^{42}$.

«las vendedoras...vendían toda clase de verduras, se apretaban en las aceras y desbordaban en el arroyo dejando libre sólo un sendero por donde desfilaban los transeúntes en fila india» ${ }^{43}$.

Ambiente popular también entre las compradoras, pues

«las señoras en Madrid por muy pobres que fuesen no iban a la compra» ${ }^{44}$. 
A diferencia de las tabernas, lugares de sociabilidad obrera masculina por excelencia, los cafés cuentan con un público más variado. Allí se dan cita gentes de todas las clases sociales, y, aunque predominan los varones, también encontramos tertulias de tipo familiar, como las referidas por Arturo Barea en el café Español ${ }^{45}$.

Por otra parte, es una época de masificación de los espectáculos, y de proliferación de cabarets y cafés cantantes. Serge Salaün ha señalado que

«el cabaret responde a una demanda sexual masiva (masculina, exclusivamente), imaginaria o concreta. La ópera y la zarzuela facilitaban una "galantería» en beneficio exclusivo de las clases altas. El cabaret amplía el consumo sexual a todas las clases» ${ }^{46}$.

El mismo autor sitúa el hecho en el marco de las diferencias de educación entre hombres y mujeres con respecto al sexo. Esas diferencias que llevan a celebrar la precocidad en las relaciones sexuales de los hijos (con prostitutas o con mujeres de clase social más baja), mientras se vigila cuidadosamente a las hijas para evitar el más mínimo desliz:

«No había pasado desapercibida en el magín del guitarrero la precocidad de Jaime con las mujeres...se sentía, como buen padre, muy gozoso con las hazañas que sospechaba de su hijo..." ${ }^{47}$.

La doble moral lastraba las relaciones entre los jóvenes de uno y otro sexo. C. Barga, refiriéndose al Madrid acomodado de principios de siglo, alude a esas

«señoritas cuya única tarea en la vida consistía en buscar, siguiendo las reglas sociales, el hombre con que se pudieran casar» ${ }^{48}$.

Y presenta a lo largo de su autobiografía el lugar que en la vida de esos hombres ocupaban las casas de prostitución, que constituían una forma habitual de iniciación en el sexo:

«Enrique lo notó y habló a solas con su amigo: "Te está interesando demasiado Marta", yo no quiero ser en lo más mínimo un obstáculo; a mí ni Marta ni ninguna mujer me influirá en mi trabajo: ¿para qué está la casa de la Granadina? Ven conmigo un día y verás cómo tomas la costumbre de ir y no te importa tanto Marta» ${ }^{49}$.

En la misma obra aparece expresada la desconfianza que ese entramado de relaciones provoca en una muchacha de clase trabajadora, educada en 
un medio anarquista, cuando el protagonista, hijo de un senador y miembro de una familia acomodada, la coge en brazos y la tumba en el suelo:

«Eso es lo que hacéis los señoritos con las modistillas» ${ }^{50}$.

Esa posición privilegiada por razón de clase y de género se refleja también en las noticias que aparecen en la prensa en enero de 1900 sobre escándalos provocados por jóvenes de familias conocidas en la ciudad, alguno de ellos abogado, que agreden a mujeres de las casas de prostitución de las calles de la Libertad y de San Marcos, y las obligan a acompañarles en comitiva por la calle durante la noche ${ }^{51}$.

En las clases altas existían reductos de hombres como el Casino o la Gran Peña, «el club de la masculinidad», en palabras de C. Barga, desde cuyos balcones los señoritos veían desfilar a las señoritas que acudían al paseo matutino en la calle de Alcalá; otros en los que vemos alternar a hombres y mujeres, como el de los salones y fiestas, y algunos de predominio femenino, como el de la beneficencia.

En el Madrid de 1900, en el que los planteamientos de reforma social sólo empezaban a abrirse paso lentamente, el enfoque habitual ante problemas como el del pauperismo y la mendicidad era el de tipo benéfico, como podemos ver en la creación de la Asociación Matritense de Caridad, en 1899, a iniciativa del Ayuntamiento, que trataba de canalizar la contribución de los particulares. En ese contexto, la caridad privada seguía teniendo un fuerte peso como forma de paliar los efectos de la pobreza, y será uno de los ámbitos de actuación de las mujeres de las clases acomodadas. La dedicación a las tareas benéficas es uno de los aspectos que se destaca en la prensa en las reseñas sobre la vida de la marquesa de Cubas, la duquesa de Veragua o la duquesa de Denia y de Medinaceli, todas ellas fallecidas en 1903. Como ejemplo de este tipo de actividades, se puede citar la Asociación de Santa Rita de Casia, que en 1903 lleva constituidos once Talleres de Caridad, donde las asociadas confeccionan prendas con destino a los más necesitados, o la Cuna del Santo Niño Jesús de Praga, que tiene por objetivo amparar a niños nacidos antes de tiempo o faltos de nutrición, ocupándose de aspectos como lactancia, vacunación, suministro de medicinas, etc., y ayudar a mujeres sin recursos que se enfrentan a su primer parto. Por su parte, la Junta de Damas de Honor y Mérito de la Sociedad Económica Matritense inicia en 1903 la construcción del Sanatorio de San José, destinado a los niños de la Inclusa y Colegio de la Paz. Una cuestión interesante sería la de indagar en qué medida se dio en esos núcleos el paso del planteamiento caritativo 
al trabajo social propiamente dicho, analizando los factores que lo dificultaron. En distintos países, esa «maternidad social» puso en contacto a mujeres de distinta procedencia social y fue el germen en que brotaron las iniciativas de numerosas reformadoras sociales ${ }^{52}$.

\section{El debate feminista}

Se ha aludido al debate que sobre el alcance de la educación de las mujeres se había desarrollado en la sociedad española en las últimas décadas del siglo XIX, a través de los Congresos Pedagógicos. Ésa sigue siendo, en el cambio de siglo, una de las cuestiones clave en la situación de las mujeres en España. Dentro de ella, la posibilidad de una educación en valores laicos, que escape al control de la Iglesia católica, es el objetivo prioritario para algunas librepensadoras, que consideran la formación de una conciencia libre como algo indispensable para la emancipación de las mujeres ${ }^{53}$.

Hay que tener en cuenta que la etapa finisecular se inscribe dentro de lo que C. Fagoaga ha llamado el período formativo del feminismo en España, previo a la fase sufragista. Resulta fundamental en esos años la acción de laicistas y librepensadoras, que se mueven en los círculos del republicanismo y las logias masónicas, enfrentándose muchas veces a los propios códigos de la masonería, en relación con el lugar de las mujeres. Los núcleos básicos de esta coordinación se sitúan en Valencia, Barcelona y Andalucía, pero en Madrid, en la época que nos ocupa será fundamental la figura de la dramaturga librepensadora Rosario de Acuña, primera mujer que ocupó la tribuna del Ateneo y del Fomento de las Artes, la segunda que estrenó en el Teatro Español (sólo la había precedido Gertrudis Gómez de Avellaneda); es al mismo tiempo una mujer que se ha separado de su marido, tras descubrir la infidelidad de éste, algo que choca con las pautas habituales de comportamiento en la época. Colaboradora de Las Dominicales del Libre Pensamiento, desde cuyas páginas se apoya a la Asociación para la Enseñanza de la Mujer, perteneció a la sociedad librepensadora «Los amigos del progreso", y la encontramos en la inauguración en Madrid de la logia femenina "Hijas del Progreso», en 1888. Al año siguiente, se produce el apoyo público desde Madrid, por parte de un grupo de diecisiete mujeres, a la carta firmada por cincuenta librepensadoras valencianas' en defensa de la libertad de conciencia, en un conflicto que las enfrenta a la jerarquía eclesiástica ${ }^{54}$. 
Las relaciones de género: Imágenes y realidad social

Que el problema de la desigualdad entre hombres y mujeres preocupaba a algunos intelectuales en la España de finales de siglo, es algo sobre lo que ha insistido recientemente G. Gómez-Ferrer. En ese marco sitúa la obra de Emilia Pardo Bazán, como intelectual de fin de siglo, perteneciente al núcleo madrileño, uno de los que reflexionan sobre los problemas que entorpecen el proceso de modernización en España. No es posible resumir aquí el contenido de su pensamiento, pero sí quiero mencionar su participación en algunos debates que se desarrollaron en aquellos años en la sociedad española en relación con el género, aparte de la cuestión educativa, ya aludida. Me refiero a temas como la posibilidad del ingreso de las mujeres en las Academias, que intentó deslindar de su caso personal y centrar en la cuestión del reconocimiento de los méritos de las mujeres, con la propuesta de Concepción Arenal para la Academia de Ciencias Morales y Políticas; la reclamación de la independencia económica a través del trabajo y la denuncia del matrimonio como única vía respetable para la mujer, a través de los modelos propuestos en sus novelas de los años 90; la existencia de la.doble moral, la reclamación de una justicia no discriminatoria, en relación con los frecuentes asesinatos de mujeres relatados en la prensa. Y todo ello, sin olvidar la difusión en España de la evolución del problema en otros países, tanto a través de la traducción de la obra de Stuart Mill, como de sus artículos sobre Congresos y reuniones feministas de carácter internacional ${ }^{55}$.

Una escritora que se sitúa en la corriente regeneracionista y que desde 1901 forma parte de la vida intelectual madrileña, a través de sus libros y su continua actividad periodística, es Carmen de Burgos, almeriense que ese mismo año obtuvo una plaza de profesora en la Escuela Normal de Maestras de Guadalajara. Primera mujer redactora de un periódico en España, con su columna diaria desde 1903 en Diario Universal, y colaboradora de $A B C$ desde ese mismo año, con su pseudónimo Colombine, desarrolla en ambas publicaciones un tipo de artículos que tratan de dar a conocer aspectos de las actividades de las mujeres en distintos países, junto a comentarios de actualidad, y temas considerados femeninos, como higiene y belleza, moda, a través de los cuales toma partido en contra de la tiranía del corsé y de cosméticos peligrosos:

«Una de las principales bellezas está en la naturalidad. Una joven, sana y hermosa, se convierte en una enferma pálida y demacrada por el abuso del corsé, creyendo aumentar su belleza al disminuir algunos centímetros su talle. Una señora de tez fresca y satinada, se convierte en una anciana de piel rugosa y amarillenta por querer aparecer con un tono más blanco y rosado dẹl que le dio la Naturaleza» ${ }^{56}$. 
Carmen de Burgos sitúa la cuestión en sus coordenadas sociales:

«La mujer quiere siempre agradar...en nuestras sociedades donde aún suele asignársele como única carrera el matrimonio, ... necesita para conseguirlo la gracia y la coquetería» ${ }^{57}$.

Un debate que Carmen de Burgos suscitó desde las páginas del Diario Universal, en diciembre de 1903, fue el relativo a la cuestión del divorcio en España. Pidió sus opiniones a intelectuales y políticos, y asimismo llegaron las cartas de numerosos lectores y lectoras, reuniendo posteriormente todo este material en un libro, que permite seguir el carácter de los argumentos esgrimidos a favor y en contra:

«El deseo de perpetuar en el libro los primeros pasos para el planteamiento de esta mejora social, nos impulsa a recopilar en un volumen todo lo dicho en el plebiscito y que no se pierda con la rapidez vertiginosa de la hoja periodística, lo que puede ser una semilla de progreso lanzada al viento, pero que en su día germinará» ${ }^{58}$.

Otra polémica que había tenido lugar en el plano internacional fue la relativa a la abolición de la prostitución reglamentada. La campaña abolicionista, apoyada en los avances médicos y el crecimiento del movimiento feminista, alcanzó sus objetivos en Inglaterra en 1886. En el caso español, fue llevada fundamentalmente por médicos, dada la debilidad del movimiento feminista. Ya entrado el siglo, se producirá el paso al abolicionismo de varios de los médicos, antiguos reglamentaristas, que habían sido responsables de la sala para prostitutas del madrileño Hospital de San Juan de Dios (en la calle Atocha, hasta 1897, y después, entre las de Menorca e Ibiza). Los capítulos dedicados al tema en la conocida obra de Hauser, publicada en 1902, constituyen un reconocimiento del fracaso de la reglamentación como forma de abordar el problema. A pesar de todo, la reglamentación se mantendrá, creándose en 1902 el Patronato Real para la represión de la Trata de Blancas, una institución de carácter benéfico, religioso y aristocrático ${ }^{59}$.

\section{Conclusiones}

Las páginas anteriores muestran algunos aspectos del sistema de relaciones de género vigente en el Madrid de 1900, un ámbito urbano de características propias, que marca diferencias respecto al mundo 
Las relaciones de género: Imágenes y realidad social

rural y respecto a otros grandes núcleos urbanos españoles, como es el caso de Barcelona, y por otra parte, respecto a lo que sucede en el momento en otras grandes ciudades europeas.

El retraso educativo español respecto a otros países del entorno hace que en 1900 todavía el género y la clase social sean factores decisivos en cuanto a las posibilidades de acceso a la educación; en ese contexto, Madrid, por su condición de capital, ofrece unas oportunidades educativas mayores que en el resto de España, si bien las diferencias de género no desaparecen. Hay que tener en cuenta que el impulso más fuerte para reducir esas diferencias corresponderá a décadas posteriores al momento analizado.

Las condiciones antisanitarias de la vida en Madrid, estudiadas por Hauser, que redundan en una elevada mortalidad, especialmente infantil, y el mantenimiento de una natalidad que trate de compensar dichas pérdidas, unidas a la insuficiencia de hospitales, a la carencia de centros de convalecientes, están en relación con una importante dedicación de las mujeres a las tareas de reproducción, es decir, a la maternidad, pero también al cuidado de niños y enfermos, y a tareas domésticas destinadas a suplir la falta de equipamientos.

Nos encontramos ante una economía que conserva aún rasgos de tipo tradicional, en la que el servicio doméstico es y seguirá siendo durante décadas el renglón más importante de trabajo del sector servicios, y es ahí donde encaja esa elevada proporción de mujeres y. su crecida tasa de soltería; la modernización del terciario en su composición todavía tardará en producirse en Madrid. Las pautas de género vigentes, y el bajo nivel de instrucción de las mujeres, producto de esas mismas pautas, dan lugar a un mercado de trabajo fuertemente segregado desde el punto de vista ocupacional y salarial, y a la existencia de un importante volumen de actividad no reconocida. No se ha desarrollado aún un sistema de protección de la maternidad, y el trabajo a domicilio se muestra inadecuado como fórmula para conciliar el trabajo de cuidado de la familia que realizan las mujeres con el que llevan a cabo para conseguir unos ingresos. No es preciso decir que el modelo teórico de varón "ganador del pan» y mujer ama de casa en exclusiva no es posible para amplias capas de la clase trabajadora, por razones económicas, y que la necesidad obliga incluso al trabajo vergonzante de las mujeres en ciertos sectores de las clases medias.

En ese contexto general se explica la importancia que alcanzan en Madrid las instituciones de beneficencia de todo tipo, ante la carencia de unos sistemas de protección social. Y si es notable la presencia femenina entre quienes se dedican a las tareas benéficas, porque se 
trata de actividades socialmente aceptadas para las mujeres de clases altas y porque disponen de tiempo, también vemos cómo los bajos salarios femeninos y la falta de protección a la maternidad hacen aparecer a muchas mujeres como destinatarias de esas ayudas.

Madrid, por su papel en la vida política e intelectual española, será lógicamente uno de los núcleos clave para seguir la evolución del debate feminista en el cambio de siglo. El cuestionamiento de las relaciones de género vigentes aparece impulsado más por la suma de una serie de iniciativas de pequeños núcleos, en los que destaca la labor de ciertas escritoras que tratan de hacer oír su voz en distintos foros, que por la acción de un movimiento feminista fuerte. La cuestión del sufragio saltará a la prensa unos años después, en 1906.

Así pues, podemos concluir afirmando que el tipo de relaciones de género que regían la vida madrileña de principios de siglo no favorecía la modernización social, si bien se observan síntomas de cambio en sectores todavía minoritarios.

\section{Notas}

1 JOVER, J. Ma: "Aspectos de la civilización española en la crisis de fin de siglo», en FUSI, J. P. y NiÑo, A. (eds.): Vísperas del 98. Orígenes y antecedentes de la crisis del 98, Madrid, Biblioteca Nueva, 1997, pp. 15 y 17.

2 Una diferencia importante entre las cifras citadas en el texto, obtenidas a partir del Censo, y las que ofrece la Rectificación del empadronamiento hecha en diciembre de 1899, A.V.S., 12-474-6, es la que afecta al distrito de Palacio, que según el Censo de 1900 cuenta con 97,6 varones por cada 100 mujeres, y según la fuente municipal de 1899 , con 74,3 , lo que le situaría en uno u otro extremo de la lista, dependiendo de la fuente utilizada.

3 Los datos sobre la proporción de casadas en Miguel, A. de: «La población de Madrid en los primeros años del siglo", Revista Española de Investigaciones Sociológicas, $\mathrm{n}^{\mathrm{0}} 19$, jul.-sept. 1982 , pp. 55-71.

4 «...en el aprecio que en el Derecho positivo de nuestro pueblo se hace de las facultades propias del hombre, según los sexos, para determinar las funciones propias del varón con las limitaciones que de su sexo nacen, se atiende muy cabalmente a su naturaleza: lo único que el hombre no puede hacer, aun en la plenitud jurídica de su personalidad, es lo que la misma naturaleza no ha querido que haga; prescindiendo de la maternidad, en el hecho fisiológico y en sus necesarias y directas consecuencias jurídicas, el hombre puede hacer cuanto socialmente hace la mujer. En cambio, ésta no puede hacer muchas cosas que no dependen de la paternidad, pero que la costumbre, los prejuicios, el ideal corriente de la vida, conceptúan impropias del sexo femenino", A. PosAdA: Feminismo, (ed. de O. Blanco), Madrid, Cátedra, 1994, pp. 208-209 (ed. original, 1899).

5 Los entrecomillados en PARDo BAZÁn, E.: «La educación del hombre y de la mujer. Sus relaciones y diferencias" (Memoria leída en el Congreso Pedagógico de 


\section{Las relaciones de género: Imágenes y realidad social}

1892), en La mujer española y otros escritos (ed. de G. Gómez-Ferrer), Madrid, Cátedra, 1999, pp. 149-177. El debate sobre la educación de las mujeres en España a partir de 1868 puede seguirse en ScANLON, G.: La polémica feminista en la España contemporánea (1868-1974), Madrid, Akal, 1986, $2^{\text {a }}$ ed., y en CAPEL MARTÍNEZ, R. Ma: «La apertura del horizonte cultural femenino: Fernando de Castro y los Congresos Pedagógicos del siglo XIX", en Mujer y sociedad en España (1700-1975), Madrid, Ministerio de Cultura, 1982, pp. 109-145.

6 Los datos de alfabetización en TIANA FERRER, A.: «Alfabetización y escolarización en la sociedad madrileña de comienzos del siglo XX (1900-1920)", en BAHAMONDE, Á. y OTERO, L. E. (eds.): La sociedad madrileña durante la Restauración, 1876-1931, vol. II, pp. 199-216. La alusión a la encuesta en SCANLON, G. M.: La polémica..., ob. cit., p. 49. Véase también BALlarín, P.: «La construcción de un modelo educativo de <utilidad doméstica>», en Duby, G. y PerRot, M. (dirs.): Historia de las mujeres, 5 vols., Madrid, Taurus, 1993, T. 4: El siglo XIX, pp. 599-611.

7 HAUSER, Ph.: Madrid bajo el punto de vista médico-social (ed. de C. del Moral), 2 vols., Madrid, Editora Nacional, 1979, T. I, p. 476. Sobre las materias de estudio, CAPEL MARTínez, R. Ma : El trabajo y la educación de la mujer en España (1900-1930), Madrid, Ministerio de Cultura, 1982, p. 406.

8 Fernández Valencia, A. y Anadón Benedicto, J.: «La formación de maestras en la Escuela Normal Central. 1858-1900", en Madrid en la sociedad del siglo XIX, 2 vols., Madrid, CAM y Revista Alfoz, 1986, vol. 2, pp. 395-411.

9 Solé Romeo, G.: La instrucción de la mujer en la Restauración.. La Asociación para la Enseñanza de la Mujer, Madrid, Universidad Complutense, 1990. Aun contando con ayudas de distintas entidades, con la colaboración gratuita de muchos profesores y con el apoyo de los socios, la magnitud de las tareas emprendidas hizo que la Asociación atravesara con frecuencia períodos de dificultades económicas; por ejemplo, ésta era la razón de que en 1910 todavía no hubiera sido posible instalar un sistema de calefacción, SOLÉ, p. 710.

10 PARDo BAZÁN, E.: «La mujer española», en La mujer española y otros escritos..., ob. cit., p. 102.

11 Ibídem.

12 DIEGo OTERo, E. de: La mujer y la pintura en la España del siglo XIX. Mujeres pintoras en Madrid: 1868-1910, 2 vols., Madrid Universidad Complutense, T. II, pp.431-505.

13 Sobre la formación de las matronas véase ORTIZ GÓMEZ, T.: «Las matronas y la transmisión de saberes científicos sobre el parto en la España del siglo XIX", Arenal, vol. 6, $\mathrm{n}^{\mathrm{o}}$ 1, en.-jun. 1999, pp. 55-79. En relación con la Escuela de Enfermeras, LÓPEZ PiÑERo, J. M.: «Rubio y Gali, Federico», en ARTOlA, M. (dir.): Enciclopedia de Historia de España, vol.. IV: Diccionario biográfico, Madrid, Alianza Edit., 1991, pp. 748-749, y SCANLON: La polémica..., ob. cit., pp. 73-74.

14 La cita en PARDo BAZÁN: "La educación...", art. cit. p. 170. El dato sobre estudiantes de Bachillerato, en CAPEL: El trabajo..., ob. cit., p. 390.

15 En 1900 estudiaban Filosofia y Letras Mercedes Sardá (que ya era profesora en la Escuela Normal Central de Maestras) y María Gracia de las Peñas, y Elvira Moragas cursaba Farmacia; ver FlECHA, C.: Las primeras universitarias en España, 1872-1910, Madrid, Narcea, 1996, pp. 150, 207, 231, 232 y 237. Sobre el Instituto Internacional, ZULUETA, C. de: Misioneras, feministas y educadoras, Madrid, Castalia, 1984.

16 Instancia de $\mathrm{M}^{\mathrm{a}}$ Dolores Martínez Rodríguez, estudiante de Farmacia, en 1889, reproducida en FleCHA, C.: Las primeras universitarias..., ob. cit., p. 132. 
17 CAPEL: El trabajo..., ob. cit., p. 404.

18 Sobre las actividades productivas en Madrid, MoRAL, C. del: La sociedad madrileña fin de siglo y Baroja, Madrid, Turner, 1974; así como NiElfa CRISTÓBAL, G.: "Madrid en la crisis finisecular», en Madrid en la sociedad..., ob. cit., vol. 1, pp. 263-283; "La economía de Madrid: desde la crisis colonial hasta el final de la Guerra Civil", en Fernández Garcfa, A. (dir.): Historia de Madrid, Madrid, Edit. Complutense, 1993, y "Mujeres: inmigración y trabajo en Madrid a lo largo del siglo XX», en AGUADO, A. (coord.): Las mujeres entre la historia y la sociedad contemporánea, Valencia, Generalitat, 1999. En relación con los Censos y las clasificaciones ocupacionales, PÉREZFUENTES HERNÁNDEZ, P.: «El trabajo de las mujeres en la España de los siglos XIX y XX: consideraciones metodológicas", Arenal, vol. 2, n 2, jul.-dic. 1995, pp. 247-268.

19 Los datos sobre equipamiento en HAUSER: Madrid bajo el punto..., ob. cit., vol. 1, pp. 313-317. Los de natalidad, en FERNÁNDEZ GARCfA, A.: «La población madrileña entre 1876 y 1931. El cambio de modelo demográfico", en BAHAMONDE y OTERO (eds.): La sociedad madrileña..., ob. cit., vol. I, pp. 29-76.

$20 \mathrm{El}$ número de lavaderos procede de elaboración propia, a partir de A.V.S., 18-129-2 y 18-130-1. Testimonios gráficos en Memoria de Madrid. Fotografias de Alfonso (selec. y textos de Publio López Mondéjar), Madrid, Ministerio de Cultura, 1984. La cita en BAREA, A.: La forja de un rebelde. T.I: La forja, Madrid, Turner, 1977, p. 17.

21 PALACIO, R. de: «Las lavanderas»; $A B C, 3-11-1903$.

22 Por ejemplo, en $A B C, 19-2-1903$. El artículo citado es SÁNCHEZ CARRERA, M ${ }^{\mathrm{a}}$ del C.: "Aproximación al estudio del trabajo de la mujer en el servicio doméstico en el Madrid de finales del siglo XIX", El trabajo de las mujeres: siglos XVI-XX. VI ${ }^{a s}$ Jornadas de Investigación Interdisciplinaria sobre la Mujer, Madrid, UAM, 1987, edic. mecanografiada, pp. 127-135. (La fuente básica utilizada ha sido la autobiografía de Corpus Barga, Los pasos contados).

23 Ministerio DE Fomento. Dirección General de Agricultura, Industria y Comercio: Memoria acerca del estado de la industria en la provincia de Madrid en el año 1905, Madrid, Establecimiento Tipográfico Hijos de J. A. García, 1907, p. LIII.

24 Blasco IbÁÑEz, V.: La horda, Madrid, Alianza, 1998, pp. 242-245. Sobre la confección, NúÑ̃E ORGAZ, A.: «Las modistillas de Madrid, tradición y realidad (18841920)", en BAHAMONDE y OTERO (eds.): La sociedad madrileña..., ob. cit., vol. II, pp. 435-450, así como CAPEL: El trabajo..., ob. cit., pp. 159-178.

25 CANDEla Soto, P.: Cigarreras madrileñas: trabajo y vida (1888-1927), Madrid, Tecnos, 1997, p. 201.

26 HAUSER, Ph.: Madrid bajo el punto..., ob. cit., vol. 1, pp. 463-465.

27 NiElfa CRISTÓBAL, G.: «Las mujeres en el comercio madrileño del primer tercio del siglo XX", en Mujer y sociedad..., ob. cit., pp. 299-332, así como Los sectores mercantiles en Madrid en el primer tercio del siglo $X X$, Madrid, Ministerio de Trabajo, 1985, y "Mercado y organización del trabajo en el comercio, 1883-1931", Estudios de Historia Social, no 30 , jul.-sept. 1984, pp. 137-148.

28 MoRATO, J. J.: "Sociedades de obreras en Madrid", $A B C, 25-8-1903$.

29 MoRATo, J. J.: «Las Juntas de Reformas Sociales», $A B C, 11-9-1903$.

30 Véase GUEREÑA, J.-L.: «El tiempo de la prostitución reglamentada. Madrid (1847-1909)", en RAmos PALOMO, M ${ }^{\mathrm{a}}$ D. y Vera BALANZA, M ${ }^{\mathrm{a}}$ T. (eds.): El trabajo de las mujeres. Pasado y presente. Actas del Congreso Internacional del Seminario de Estudios Interdisciplinarios de la Mujer, 4 vols., Málaga, 1996, vol. II, pp. 53-75; MoRAL, C. del: La sociedad..., ob. cit.; WALKOWITZ, J.: "Sexualidades peligrosas", en 


\section{Las relaciones de género: Imágenes y realidad social}

DUBY y PERROT (dirs.): Historia de las..., ob. cit., T. 4: El siglo XIX, pp. 369-385; BARGA, C.: Los pasos contados. T. 3: Las delicias, Barcelona, Bruguera, 1985.

31 Sobre el Registro del Trabajo, NIELfa CRISTÓBAL, G.: "El "Registro del Trabajo" del Ayuntamiento de Madrid y el problema social en los umbrales del siglo XX (18991900)", en Estudios de Historia de España. Homenaje a Manuel Tuñón de Lara, 2 vols., Madrid, Universidad Internacional Menéndez Pelayo, 1981, vol. 1, pp. 465-479. En relación con el concepto de mujer trabajadora en el siglo XIX, ScOTT, J. W.: «La mujer trabajadora en el siglo XIX", en DUBY y PERROT (dirs.): Historia de las..., ob. cit., T. 4, pp. 405-435.

32 PARDO BAZÁN, E.: "La España de ayer y la de hoy", en La mujer española y..., ob. cit., p. 309. Sobre el trabajo de las mujeres en Correos y Telégrafos en esta época, véase FRANCO RUBIO, G.A.: La incorporación de la mujer a la administración del estado, municipios y diputaciones, 1918-1936, Madrid, Dirección General de Juventud y Promoción Socio-Cultural, 1981, pp. 45-48.

33 Ballarín Domingo, P.: «Maestras, innovación y cambios», Arenal, vol. $6, \mathrm{n}^{\circ} 1$, en.-jun. 1999, pp. 81-110; ANADÓN, J. y FERNÁNDEZ, A.: «El profesorado femenino de la Escuela Normal Central de Maestras de Madrid, 1858-1900", en El trabajo de las mujeres, siglos XVI-XX. VIas Jornadas..., ob. cit., pp. 233-241.

34. Las noticias sobre esas médicas pioneras, en FLECHA, C.: Las primeras universitarias..., ob. cit., pp. 197-204. Sobre el objetivo de la Hermandad de la Esperanza, Simón PALMer, $\mathrm{M}^{\mathrm{a}}$ del C.: La mujer madrileña del siglo XIX, Madrid, Ayuntamiento e Instituto de Estudios Madrileños, 1982, p. 23.

35 JULIÁ, S.: "Madrid, capital del Estado (1833-1993)», en JULIÁ, S.; RINGROSE, D. y Segura, C.: Madrid. Historia de una capital, Madrid, Alianza, 1994, p. 344.

36 Sobre las escritoras, Simón PALMER, $\mathbf{M}^{\mathrm{a}}$ del C.: Escritoras españolas del siglo XIX. Manual bio-bibliográfico, Madrid, Castalia, 1991. Véase también MATILla, $\mathrm{M}^{\mathrm{a}} \mathrm{J}$. y FraX, E.: «El siglo XIX», en ORTEGA, M. (dir.): Las mujeres de Madrid como agentes de cambio social, Madrid, IUEM de la UAM, 1995, pp. 57-175.

37 La cita en AUBERT, P.: "Madrid, polo de atracción de la intelectualidad a principios de siglo", en BAHAMONDE y OTERO (eds.): La sociedad madrileña..., ob. cit., vol. II, pp. 101-137.

38 Diego OTERo, E. DE: La mujer y la pintura..., ob. cit., T. II, p. 657. Sobre la actividad profesional de las pintoras, véase el cap. segundo de la $2^{\mathrm{a}}$ parte.

$39 A B C, 30-6-1903$.

40 Sobre la "Unión de pintoras y escultoras» en Francia, véase HigonNeT, A.: "Las mujeres y las imágenes. Apariencia, tiempo libre y subsistencia», en DUBY y PERROT (dirs.): Historia de las..., ob. cit., T. 4, p. 287.

41 Laffitte, M. (CAmpo Alange, Condesa de): La mujer en España. Cien años de su historia, 1860-1960, Madrid, Aguilar, 1964, p. 259 (véase también p. 134).

42 El Liberal, 15-10-1900 y 18-12-1900. La obra aludida es PerRot, M.: Mujeres en la ciudad, Santiago de Chile, Edit. Andrés Bello, 1997.

43 BARGA: Las delicias..., ob. cit., pp. 199-200.

44 Ibídem, p. 212.

45 BAREA: La forja..., ob. cit., pp. 28-34.

46 SALAƯN, S.: «Méritos, tapujos y vergüenzas de Talía: los espectáculos en España hacia 1900", en RUIZ MANJÓN-CABEZA, O. y LANGA, A.: Los significados del 98. La sociedad española en la génesis del siglo XX, Madrid, Biblioteca Nueva y UCM, 1999, p. 555.

47 BARga, C.: Las delicias..., p. 223. 
48 Ibidem, pp. 117-121.

49 Ibidem, p. 180.

50 Ibídem, p. 302.

51 El Liberal, 13-1-1900, 14-1-1900, 17-1-1900 y 19-1-1900.

52 Acerca de la Asociación Matritense de Caridad, NIELFA: «El "Registro del Trabajo"...", art. cit. El papel de la caridad privada en lo que se refiere a la protección de la infancia se puede seguir en la Tesis Doctoral inédita de $\mathrm{M}^{\mathrm{a}}$ LUISA RAMAS VARO La infancia trabajadora, mendiga y abandonada de Madrid: legislación, ideología y realizaciones de 1900 a 1914, leída en el Departamento de Historia Contemporánea de la UNED en junio de 2000. Las reseñas sobre las aristócratas, en $A B C$, 4-6-1903, 21-7-1903 y 14-8-1903. Sobre las otras organizaciones benéficas citadas, véase «Crónica del Bien», $A B C$, 5-2-1903, 14-5-1903, 26-6-1903, y «El Sanatorio de San José», $A B C$, 1-12-1903. Para el paso de la caridad al trabajo de reforma social, PERROT, M.: "Salir», en DUBY y PERRot (dirs.): Historia de las..., ob. cit., T. 4, pp. 462-468.

53 FAGOAGA, C.: "De la libertad a la igualdad: laicistas y sufragistas», en SEGURA, C. y NiELfa, G. (eds.): Entre la marginación y el desarrollo: Mujeres y Hombres en la Historia. Homenaje a María Carmen García-Nieto, Madrid, Instituto de Investigaciones Feministas de la UCM y Ediciones del Orto, 1996, pp. 171-198, y RAMOS, $\mathrm{M}^{\mathrm{a}}$ D.: "La construcción de la ciudadanía femenina: las librepensadoras (1898-1909)», en FAGOAGA, C.(coord.): 1898-1998. Un siglo avanzando hacia la igualdad de las mujeres, Madrid, CAM, 1999, pp. 91-116.

54 Sobre Rosario de Acuña, Simón Palmer, Ma del C.: «Mujeres rebeldes», en Duby y Perrot (dirs.): Historia de las..., ob. cit., T. 4, pp. 629-641. El último punto, en FAGOAGA, C.: «De la libertad a..., art. cit., p. 177.

55 PARdo BAzÁN, E.: La mujer española y ..., ob. cit.; Gómez-Ferrer, G.: «La situación jurídica de las mujeres a finales del XIX: el discurso de Emilia Pardo Bazán", en FAGOAGA, C. (coord.). 1898-1998. Un siglo..., ob. cit., pp.15-44, y «Emilia Pardo Bazán en el ocaso del siglo XIX", Cuadernos de Historia Contemporánea, n 20, Madrid, 1998, pp. 129-150.

56 ColOMBINE: «Lecturas para la mujer. Higiene de la belleza», Diario Universal, 8-1-1903. Es conocida la importancia de la rebelión contra la tiranía de la moda, y en especial, contra los efectos perniciosos del corsé, en los movimientos de emancipación de las mujeres de finales de siglo; véase, por ejemplo, LITVAK, L.: Erotismo fin de siglo, Barcelona, Antoni Bosch editor, 1979, pp. 169-172. Sobre C. de BuRgos, véase NúÑEZ, C.: "Carmen de Burgos en la Generación del 98», en FAGOAGA, C. (coord.): 1898-1998. Un siglo..., ob. cit., pp. 77-90.

57 Colombine: Ibídem.

58 Burgos Seguí, C. (Colombine): El Divorcio en España, Madrid, M. Romero, impresor, 1904.

59 Rivière Gómez, A.: “Caídas, Miserables, Degeneradas». Estudios sobre la prostitución en el siglo XIX, Madrid, CAM y Edit. horas y Horas, 1994, pp. 72-94; HAUSER: Madrid bajo el punto..., ob. cit., T. 2, pp. 133-155 у 19? 209. 